\title{
IMPACT OF TECHNOLOGICAL CHANGE ON GROWTH AND AGRICULTURAL SECTOR IN GUJARAT STATE OF INDIA: A TIME- SERIES DATA STUDY
}

\author{
Shah Nawaz \\ Ashraf ${ }^{1}$ \\ Ajay K. Singh ${ }^{2+}$
}

\author{
${ }^{\prime} F P M$ (Doctoral Research) Student, Entrepreneurship Development Institute \\ of India Ahmedabad, Gujarat, India. \\ Email:shah.ashraf2013@gmail.com Tel:+916355181330 \\ 'Assistant Professor (Economics), School of Liberal Arts and Management, \\ DIT University, Dehradun, Uttarakhand, India. \\ Email:a.k.seeku@gmail.com Tel: +917566569201
}

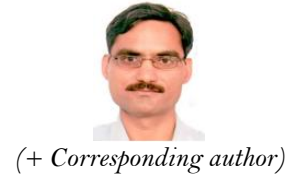

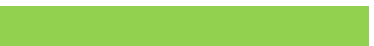

Article History

Received: 30 July 2021 Revised: 25 August 2021 Accepted: 10 September 2021 Published: 27 September 2021

\section{Keywords}

Agricultural sector Growth rate Gujarat

Technological change

Yield of food-grain

Commercial crops

Growth rate mode

Cobb-Douglas production

Function model.

JEL Classification: $\mathrm{N} 15, \mathrm{~N} 75, \mathrm{Q} 18, \mathrm{O} 32, \mathrm{O} 33$.

\section{ABSTRACT}

This study assessed the growth rate of commercial and food-grain crops due to technological change in Gujarat. Growth rate model was employed to examine the growth rate of area sown, production and yield of crops. Subsequently, impact of technological change, and other inputs on yield of individual crop was estimated using a Cobb-Douglas production function model. Time trend factor was used as a proxy variable to capture the impact of technological change, and other inputs (i.e., area sown, irrigated area, application of fertilizer, agricultural labors, rural literate population and annual actual rainfall) on yield of crops. Growth rate of cropped area, production and yield of cotton, sugarcane, castor, potato, rice, arhar, maize, gram and wheat crops were seemed positive in Gujarat. Yield of cotton, sugarcane, castor, rice, arhar, maize, bajra, gram, wheat, jowar ragi, potato, groundnut, sesamum, rapeseed\&mustard and soyabeans crops was positively associated with time trend factors. Furthermore, the regression coefficient of time trend factor with yield of cotton, tobacco, potato, groundnut, sesamum, rapeseed \& mustard, rice, arhar, maize, bajra, gram, wheat, jowar and ragi was reported positive and statistically significant. Hence, the estimates shows that yield of aforesaid crops were improved due to application of technological change in agricultural sector in Gujarat. Several practical policy suggestions are given to increase the use of technology in agricultural sector to improve the growth of major food-grain and commercial crops.

Contribution/ Originality: This study is a significant contribution to the existing literature which examines the impact of technological change on area shown, production and yields of major food-grain and cash crops in Gujarat using a time series data. It provides practical policy proposals to increase the use of technology in agricultural sector.

\section{INTRODUCTION}

Technological change is useful to increase sustainable farming, rural upliftment, and livelihood security and farmer's empowerment (Abdullahi, Mahieddine, \& Sheriff, 2015; Chakrabarti et al., 2002; Deb, Mandal, \& Dey, 1991; Gebeyehu, 2016; Joshi, 2012; Kapur, 2018; Mittal \& Tripathi, 2009; Pingali, Aiyar, Abraham, \& Rahman, 2019). Discovery of plant biotechnology and Bt cotton are the fruit of technological change and agricultural innovation in India. Applications of technological change in cultivation is directly associated with mechanization of farming activities (Sinha, 2019). Use of machine and modern technique in agricultural sector known as 
mechanization. Mechanization is based on capital intensive technology to increase the agricultural productivity. It includes tractor, thresher, harvesters, chemical technologies, HYV technology and other technological devices for levelling, spraying, weeding application of fertilizers, pesticide, bio-fertilizers and water irrigation in agricultural sector. Mechanization is very useful to increase the agriculture production and quality of products. It also increases the choices for growing of multiple and diversification of crops in agricultural sector. Technological change is useful to increase the efficiency and productivity of land and labours and competitiveness among the small holders (Sinha, 2019). It also allows effective use of inputs such as seeds, pesticide, fertilizer, labour and water. Subsequently, land productivity and employment opportunities are likely to increase as use of new technology in agricultural sector (Basant, 1987; Chakrabarti et al., 2002). Therefore, the technologies are essential to increase the Agri industrial growth and socio-economic development (Ghadiryanfar, Keyhani, Akram, \& Rafiee, 2009; Sinha, 2019).

In India, farmers are using various agricultural technologies to increase yield, area and production of crops since post-independence period (Saurabh, 2016). Subsequently, the agricultural technologies could provide effective support to increase economic growth, and reduce the stress of poverty with maintaining the livelihood security and food security of rural and urban dwellers in India (Pingali et al., 2019). There are several examples which show the progress of technological change in Indian agricultural sector. Genetically modified cotton crop is a good example of technological change in Indian agriculture (Kapur, 2018). Profit of farmers has increased due to use of biotechnology cotton in cultivation and it also reduces the use of chemical fertilizer in cultivation of cotton crop in India. Technological change plays a significant role to maintain the crop productivity in India. For instance, Rao (2007) have provided a concreate review on importance on ICT in Indian agricultural sector. Pasa (2017) have claimed that technological change is effective to increase commercialization of farming, income of farmers, selfemployment, rural development and agricultural development. However, application of tradition crop rotation, local farming techniques, green technologies and green fertilizer in farming also have a vital contribution in sustainable agricultural development (Zilberman, Khanna, \& Lipper, 1997). Furthermore, drip irrigation is systematic technique that is useful to conserve water and reduce drainage in agriculture sector (Zilberman et al., 1997).

In India, several researchers have examined the effect of various socio-economic variables and organic farming on yield and production of crops; monetary value of agricultural production, per hectare value of production and agricultural GDP at district level, regional level, state level and national level data using secondary and primary data. Previous studies have also used agricultural production data in form of cross-sectional, time series and panel data to assess its association with climatic factors, fertilizer, high yielding varieties of seeds, female labours, literate farmers, farm management practices, irrigation facilities, ecological services, geographical location, credit facilities, government expenditure and rural development, agricultural extension services, agricultural $\mathrm{R} \& \mathrm{D}$, technological change and others (e.g., (Birthal, Khan, Negi, \& Agarwal, 2014; Desai, 1994; Eyhorn, van den Berg, Decock, Maat, \& Srivastava, 2018; Hazarika, Manoj, Thakuria, \& Bordoloi, 2013; Jyoti \& Singh, 2020; Kumar, Rupa, Ashrit, Deshpande, \& Hansen, 2004; Kumar, 2015; Kumar, Sharma, \& Ambrammal, 2015a; Kumar, Ahmad, \& Sharma, 2017; Pandey, Crawford Jr, \& Maranville, 2002; Patil, Reidsma, Shah, Purushothaman, \& Wolf, 2014; Singh \& Jyoti, 2021 a, 2021 b; Singh, Sharma, \& Singh, 2016; Singh, Narayanan, \& Sharma, 2017; Sinha, 2019; Yadav et al., 2013).

Furthermore, a group of researchers have assessed the role of ecosystem services i.e., soil, land use change, types of soil, water, water scarcity, natural resources degradation, pasture-forest degradation, deteriorated water quality, ground water depletion, forestry, and air in agricultural production system in India (Kumar et al., 2004; Kumar, 2011; Kumar, \& Sharma, 2014). Few studies have assessed the impact of agricultural practices on ecosystem services in different districts of India (Davari, Ram, Tewari, \& Kaushish, 2010). Few studies have focussed their investigation to assess the influence of high yielding varieties of seeds on agricultural productivity in India (Basant, 1987; Shabbir \& Yaqoob, 2019). Another group of researchers have also examined the impact of organic farming on agricultural production in India (Eyhorn, Ramakrishnan, \& Mäder, 2011; Eyhorn et al., 2018; Forster et al., 2013; Hazarika et al., 2013; Kumar et al., 2004; Patil et al., 2014; Suresh, 2010). Moreover, numerous studies have 
assessed the role of technological change in Indian agricultural sector. For instance, Basant (1987) have observed that influence of agriculture technologies on employment in India. Desai (1994) have examined the contribution of technological change in Indian agricultural sector. Chakrabarti et al. (2002) have analysed the impact of new agricultural technologies on economic situation of agricultural labour in India. Basavaraja, Mahajanashetti, and Sivanagaraju (2008) have examined that technological change in paddy production in India. Mittal and Tripathi (2009) have investigated the importance of mobile phone technology in Indian agriculture sector. Chandrashekar (2010) have also reviewed the important of modern technologies in agricultural production in India. Shanthy (2011) have claimed that smooth and effective dissemination of technologies could provide significant benefits to the sugarcane growers in India. Joshi (2012) have assessed the significance of science \& technology for revival of Indian agriculture sector. It reported that science and technology is useful to transform the position of agricultural sector towards Agri-entrepreneurship. Suryavanshi and Singh (2014) have noticed that biotechnology has provided several ways to sustain the productivity of crops and nutritional quality of food-grain products in India. Reddy, Roy, and Tiwari (2014) have observed the positive impact of technologies in Indian agriculture. Saurabh (2016) have examined the economic impact of agricultural technologies in Indian agriculture. Kapur (2018) have reviewed the usages of technologies in agriculture sector of India. Shabbir and Yaqoob (2019) have assessed the influence of technological change on total factor productivity (TFP) of cotton crop in India and Pakistan. Pingali et al. (2019) have reported that agricultural technologies are useful to increase competitiveness of small holder in India. Sinha (2019) have examined the impact of agricultural technologies on growth of agriculture sector in Bihar (India). Siddick (2019) have examined the role of appropriate technologies in improving of yield and income of farmers in India.

As per the aforementioned review, it is clear that existing researchers and agricultural economists have included the most factors to assess their impact on agriculture sector in India. However, limited studies could provide the concrete understanding on implications of technological change on growth pattern and yield of foodgrain and cash crop at state level in India using a time series analysis. Thus, this study is a fresh attempt which assess the influence of technological change on production, yield and cropped area of food-grain and commercial crops in Gujarat state of India. This investigation could be helpful to understand that productivity of which crop have improved due to application of technological change in agriculture sector of Gujarat. Accordingly, this study is addressed some specific research questions with regards to technological change, growth pattern and yield of foodgrain and commercial crop in Gujarat. These research questions are given as:

- What is impact of technological change on growth rate of food-grain and commercial crops in Gujarat?

- Whether the impact of technological change and other inputs on yield of food-grain and commercial crops varies or not in Gujarat?

- What should be policy action initiatives to increase the practices of technology in agricultural sector of Gujarat?

With associated to aforementioned research questions, this study is achieved following objectives?

- To analyses the growth pattern of cropped area, production and yield of food-grain and commercial crops in Gujarat using secondary data.

- To assess the impact of technological change on yield offood-grain and commercial crops in Gujarat using secondary data.

- To provide the practical implications to increase the use of technology in agricultural sector in India.

\section{METHODS AND MATERIALS}

\subsection{Study Area}

The study area of this research was Gujarat. Gujarat is located on the western coast and it has a largest coastline of $1600 \mathrm{~km}$ in India. It occupies geographical area of 196,024 square $\mathrm{km}$. Gujarat is one of the fastest growing states of India. Gujarat's strong industrial policies have a significant contribution to increase economic 
development and gross state domestic product. The state is dominated in many industries which have the reputation in India. Chemical, textile, petrochemicals, drugs and pharmaceuticals, dairy, cement, Agro and food processing, ceramics, engineering, gems and jewellery, auto components, oil and gas, IT and power industries have a greater contribution in India. It is also the largest producer of diamonds which counts around $72 \%$ production of the world. It also contributes around $80 \%$ diamond exports in India. Furthermore, Gujarat is a center of chemical industries which counts around 35\% of chemical production of India. Therefore, the state has excellent industrial infrastructure environment as compared to other Indian states. ${ }^{1}$ Agriculture sector of Gujarat shows a significant and positive growth rate in last decade in India (Pattnaik \& Shah, 2015). The agriculture, secondary and service sectors could contribute around $11.24 \%, 40.08 \%$ and $48.68 \%$ share respectively, in Gujarat's SDP during 2013-14.

\subsection{Data Source}

Required data for this study was taken from various sources. Production, cropped area and yield of food-grain, cash crop, horticulture and oilseed crops were derived from the online data base of Centre Monitoring Indian Economy (CMIE) Private Limited. Gross sown area and gross irrigated area were also taken from aforementioned website. Number of agricultural labours was obtained from the different publication of Policy Commission (GoI). Annual actual rainfall was taken from Indian Meteorological Department (GoI) and Official Website of International Crops Research Institute for the Semi-Arid Tropics (ICRISAT), Hyderabad.

\subsection{Formulation of Empirical Models}

As scientific research community have discovered different agricultural technologies to increase the production, cropped area and yield of individual crop. However, a specific technology can be used for a particular crop. While, few technologies such as tractor and threshers can be used for multiple purpose in agriculture sector. Therefore, the impact of a technology on agricultural production and productivity cannot be measured easily (Abdullahi et al., 2015). Hence, growth rate and Cobb-Douglas production function models were used to assess the impact of technological change on growth pattern and yield of food-grain and commercial crops in Gujarat.

\subsection{Growth Rate Model}

Previous studies have estimated the growth of an individual crop to understand the progress of it's in a specific time period. This is an effective to gauge the influence of technological change on yield and production of a crop (Khan \& Anwar, 2009; Kumar et al., 2015a; Pattnaik \& Shah, 2015). Previous studies have claimed that the growth rate model is highly useful in those areas where new land is still available. This model assumes that production will increase at constant rate. Hence, the model is greatly effective to capture the influence of technological change on yield, production and area of food-grain and cash crops. Growth rate model was used to measure the influence of technologies on agricultural sector in Gujarat (Kannan, 2011). For this, area sown, production and yield of major crops were used as a response variable, and time trend factor was used as an autonomous variable (Pattnaik \& Shah, 2015). This investigation includes the production, area sown and yield of cotton, sugarcane, tobacco, castor, arhar, rice, bajra, maize, wheat, gram, jowar, potato, ragi, groundnut, sesame, rapeseed \& mustard, soybean and cotton seeds crops during 1971-2013 at state level in Gujarat. However, the data was limited for rapeseed \& mustard and soybean crops. Compound interest rate formula was used to develop the growth rate model for aforesaid crops. The formula was used as:

$$
\Upsilon_{t}=Y_{0}(1+r)^{t}
$$

Here, $r$ is the (i.e., over time) growth rate of $Y_{t}$ (i.e., is the yield, production and area sown of respective crops), $t$ is time period. After using the natural logarithm of Equation 1 that was explained as:

\footnotetext{
1http://www.ibef.org/states/gujarat.aspx
} 


$$
\ln \Upsilon_{t}=\ln Y_{0}+t \ln (1+r)
$$

Here, assuming that $\beta_{1}=\ln \gamma_{0}$ and $\beta_{2}=\ln (1+r)$. The Equation 2, therefore, can be expressed as:

$$
\ln \gamma_{t}=\beta_{1}+\beta_{2} t
$$

After adding the error term, Equation 3 is used as:

$$
\ln \gamma_{t}=\beta_{1}+\beta_{2} t+u_{t}
$$

The model is similar to linear regression model in that parameter i.e., $\beta_{1}$ and $\beta_{2}$ are linear. Here, $\beta_{2}$ measures the growth rate in production, yield and area sown of respective crops in Equation 4.

\subsection{Cobb-Douglas Production Function Model}

Existing studies have used different factors such as time trend factor $(T T F)$, fertilizer intensity, tractor intensity, education of labour force, improved seed, fertilizer, pesticide and herbicide, farm management practices, and farmer's experience as a proxy variable to examine the influence of technological change on production and yield of various crops in different countries (Gebeyehu, 2016; Khan \& Anwar, 2009; Kumar, Sharma, \& Joshi, 2015b; Siddick, 2019; Singh \& Jyoti, 2021a, 2021b; Singh \& Sharma, 2018; Singh et al., 2017). TTF is highly effective to assess the impact of technological change on agricultural production. Thus, this study also used TTF to capture the influence of technological change on yield of food-grain and commercial crops (i.e., Rice, Arhar, Maize, Bajra, Gram, Wheat, Jowar and Ragi, Cotton, Sugarcane, Tobacco, Castor, Potato, Groundnut, Sesamum, Rapeseed \& Mustard and Soyabeans) in Gujarat during 1971 - 2017. Time series data for Tobacco, Castor, Rapeseed \& Mustard and Soyabeans crops were available during 1977-2017. For aforesaid investigation, yield of an individual crop was used as a dependent variable. While, $T T F$, area sown, irrigated land, consumption of fertilizer/hectare land, application of agricultural labour per hectare land, contribution of literate rural population in total cropped area and annual actual rainfall were used as independent variables.

Cobb-Douglas production function model (C-D production model) produce consistent coefficient of independent variables with output in agricultural production analysis (Kumar, 2015; Kumar et al., 2015a; Kumar, \& Sharma, 2014; Kumar, et al., 2015b; Kumar, Sharma, \& Joshi, 2016). Desai (1994); Basavaraja et al. (2008); Sinha (2019) have also used C-D production model to observe the influence of technological change and other inputs on yield and production of various crops in India. The statistical interpretation of regression coefficients of independent variables which are estimated using C-D production model is easy and simple (Kumar, Singh, \& Sharma, 2020; Singh \& Sharma, 2018; Singh et al., 2017). Furthermore, regression results based on this model can be used to predict the future values of output (Jyoti \& Singh, 2020; Kumar et al., 2017; Singh \& Jyoti, 2021 a, 2021 b). Thus, C-D production model was applied to estimate the regression coefficient of independent variables in this study. This study accepts that yield of a specific crop depends upon area sown, irrigated area, application of fertilizer and agricultural labour, literate population and rainfall. The functional form of yield of crop with independent variables is specified as:

$$
(L P)=f(A S, G I A, F A P H L, A L P H L, L R P P H L, A A R F)
$$

Here, $L P$ is yield of a specific crop, $A S$ is cropped area under this crop, GIA is the irrigated area, FAPHL is the application of fertilizer on per hectare land, $A L P H L$ is the use of agricultural workers on per hectare arable land, $L R P P H L$ is the ratio of rural literate population with gross sown area and AARF is the annual actual rainfall in Equation 5. C-D production model was used as:

$\log (l p)_{i}=\beta_{0}+\beta_{1}(T T F)+\beta_{2} \log (A S)_{t}+\beta_{3} \log (G I A)_{t}+\beta_{4} \log (F A P H L)_{t}+\beta_{5} \log (A L P H L)_{t}+\beta_{6} \log (\text { LRPPHL })_{t}+\beta_{7} \log$ $(A A R F)_{t}+v_{t}$

Here, $\log$ is the logarithm of associated dependent and independent variables, $\beta_{0}$ is constant coefficient that measure the total factor productivity $(T F P)$ (Kumar et al., 2016). It also assumes that above-mentioned function is constant return to scale and $v_{t}$ is error term. $\beta_{1}, \beta_{2}, \ldots, \beta_{7}$ are the elasticities of related variables; and $t$ is time period i.e., 1971-2017 in Equation 6. The brief description of dependent and independent variables is given in Table 1. 
Table-1. Summary of the dependent and independent variables.

\begin{tabular}{l|c|c}
\hline Variables & Symbol & Units \\
\hline Land productivity of a specific crop & LP & Kg./Ha. \\
\hline Time trend factor & TTF & Number \\
\hline Area sown of a specific crop & AS & Ha. \\
\hline Irrigated area & GIA & Ha. \\
\hline Application of fertilizer on per hectare land & FAPHL & Kg./Ha. \\
\hline Use of agricultural labour per hectare land & ALPHL & Number \\
\hline Ratio of literate population with gross sown area & LRPPHL & Number \\
\hline Annual actual rainfall & AARF & mm \\
\hline
\end{tabular}

\subsection{Process for Selection of Appropriate Model}

As this study used time series data of cropped area, production and yield of 17 crops; irrigated area, application of fertilizer, application of agricultural labour, ratio of literate population with gross sown area and annual actual rainfall. Therefore, it was essential to check normality, stationarity and non-stationarity, existence of unit root test, existence of multi-correlation, autocorrelation and heteroscedasticity in the time series data. Hence, this study was used following process to choose a suitable empirical model. Ramsey RESET test was used to check the functional form of the purposed model for fitted values of yield and explanatory variables (Jyoti, \& Singh, 2020; Singh, 2017). The statistical values under Ramsey RESET test show that the functional form of the log-linear model was found well specified See Table 2. Variance inflation factor (VIF) values for individual crop was estimated to check the presence of multi-correlation (Singh, \& Sharma, 2018). Cameron and Trivedi's decomposition of IM-test and Breusch-Pagan/Cook-Weisberg tests were used to address the problem of Heteroscedasticity (Singh, \& Sharma, 2018). Durbin-Watson d-statistic, Durbin's alternative test and Breusch-Godfrey LM tests were applied to distinguish the presence of auto-correlation in time series (Kumar et al., 2020; Singh, \& Sharma, 2018).

\section{RESULTS ON GROWTH RATE AND TECHNOLOGICAL CHANGE}

\subsection{Growth Rate of Commercial Crops}

In this study, time trend factor $(T T F)$ was used a proxy for technological change to measures its influence on cropped area, production and yield of selected 17 crops. Since, it used state-level information in a time series during 1971-2013. Therefore, it checks the normality of each time series for each crop recursively. Previous studies have claimed that if values of skewness and kurtosis lie between -1 to +1 , thus, the time series can be considered normally distributed (Jyoti, \& Singh, 2020). Table 3 includes the growth of cropped area, production and yield of commercial crops. The values of skewness were lie between -1 to +1 . Thus, estimates show the time series of all cash crops were normally distributed. Thus, time series data for these crops can be used for further empirical investigations. Moreover, $F$-values were also found statistically significant for most crops. Values of $R^{2}$ show the significant variation in cropped area, production and yield of crops due to technological change.

The results based on $R^{2}$ value, infer that production and yield of cotton crop, cropped area, and production of sugarcane, cropped area, and production of castor crop have a greater dependency on technologies in farming. The regression coefficients of time trend factor with cropped area and yield of cotton, sugarcane and castors were found positive and statistically significant. 
Table-2. Results of hypothesis testing for selection of appropriate empirical model.

\begin{tabular}{|c|c|c|c|c|c|c|c|}
\hline Crops & VIF & $\begin{array}{c}\text { Ramsey RESET } \\
\text { test for fitted } \\
\text { values of crop yield }\end{array}$ & $\begin{array}{c}\text { Ramsey RESET test } \\
\text { for independent } \\
\text { variables }\end{array}$ & $\begin{array}{c}\text { Breusch-Pagan/Cook- } \\
\text { Weisberg test for } \\
\text { heteroskedasticity }\end{array}$ & $\begin{array}{c}\text { Cameron \& Trivedi's } \\
\text { decomposition of } \\
\text { IM-test }\end{array}$ & $\begin{array}{c}\text { Durbin's } \\
\text { alternative test for } \\
\text { autocorrelation } \\
\end{array}$ & $\begin{array}{c}\text { Breusch-Godfrey } \\
\text { LM test for } \\
\text { autocorrelation } \\
\end{array}$ \\
\hline Cotton & 60.14 & $3.75^{*}$ & $5.82^{*}$ & $0.00^{*}$ & 54.56 & $6.030^{*} *$ & $6.437 * *$ \\
\hline Sugarcane & 68.25 & 1.19 & $4.51^{*}$ & 0.89 & 42.03 & $4.203^{*}$ & $4.681^{*}$ \\
\hline Tobacco & 51.29 & $49.10^{*}$ & 0.000 & 0.31 & 26.82 & 0.321 & 0.547 \\
\hline Castor & 46.94 & $13.07 *$ & $9.51^{*}$ & 2.07 & 49.24 & $3.455^{* * * *}$ & $3.995 * *$ \\
\hline Rice & 46.76 & $5.83 *$ & $1.98^{*}$ & $18.76^{*}$ & $57.07 * * * *$ & $4.988^{* * *}$ & $5.454 * *$ \\
\hline Arhar & 59.07 & 1.60 & 1.40 & 1.15 & 53.74 & 2.156 & 2.523 \\
\hline Maize & 40.68 & 1.44 & $1.97 * * *$ & $4.02 * *$ & 52.40 & 0.070 & 0.086 \\
\hline Bajra & 36.46 & $5.50^{*}$ & $1.82 * * *$ & $4.84 * *$ & 36.97 & 0.047 & 0.058 \\
\hline Gram & 36.46 & $5.94^{*}$ & 1.47 & 0.60 & 34.55 & 0.489 & 0.597 \\
\hline Wheat & 46.37 & 0.12 & 0.67 & 0.04 & 37.31 & $4.132 * *$ & $4.609^{*} *$ \\
\hline Jowar & 63.76 & 1.38 & 0.74 & $10.87^{*}$ & 47.87 & 0.063 & 0.077 \\
\hline Ragi & 40.7 & 1.70 & 1.18 & 0.34 & 45.82 & 1.224 & 1.466 \\
\hline Potato & 50.32 & 0.18 & 0.39 & 0.41 & 40.15 & 2.293 & 2.675 \\
\hline Groundnut & 38.18 & 1.05 & 0.53 & 1.41 & 46.06 & 5.939 & $6.352^{* * * *}$ \\
\hline Sesamum & 33.39 & 16.28 & 1.33 & $38.16^{*}$ & $59.70^{* *}$ & 0.359 & 0.44 \\
\hline $\begin{array}{c}\text { Rapeseed \& } \\
\text { Mustard }\end{array}$ & 52.16 & $5.68^{*}$ & 1.34 & $7.25^{*}$ & 44.81 & 1.819 & 2.205 \\
\hline Soyabean & 47.62 & 0.78 & $2.77 * *$ & $21.19^{*}$ & 56.72 & $6.348 * *$ & $6.728^{*}$ \\
\hline
\end{tabular}


Table-3. The growth rate in cropped area, production and yield of commercial crops.

\begin{tabular}{|c|c|c|c|c|c|c|c|c|c|}
\hline Crops & \multicolumn{3}{|c|}{ Cotton } & \multicolumn{3}{|c|}{ Sugarcane } & \multicolumn{3}{|c|}{ Tobacco } \\
\hline Components & $\begin{array}{l}\text { Area } \\
\text { sown }\end{array}$ & Production & Yield & $\begin{array}{l}\text { Area } \\
\text { sown }\end{array}$ & Production & Yield & Area sown & Production & Yield \\
\hline Skewness & 0.694 & 0.624 & 0.089 & -0.193 & -0.497 & -0.399 & 0.531 & 0.99 & 0.634 \\
\hline No. of Obs. & 43 & 43 & 43 & 43 & 43 & 43 & 17 & 17 & 17 \\
\hline F-Value & $7.19^{*}$ & $0.4859^{*}$ & 56.41 * & $194.02^{*}$ & $123.27^{*}$ & $10.7^{*}$ & 0.06 & 0.21 & 1.98 \\
\hline Prob $>F$ & 0.011 & 0.000 & 0.000 & 0.000 & 0.000 & 0.002 & 0.805 & 0.654 & 0.179 \\
\hline$R^{2}$ & 0.149 & 0.486 & 0.579 & 0.826 & 0.75 & 0.207 & 0.004 & 0.014 & 0.117 \\
\hline Adj. $R^{2}$ & 0.128 & 0.473 & 0.569 & 0.821 & 0.744 & 0.188 & 0.062 & 0.052 & 0.058 \\
\hline$T T F$ & 0.009 & 0.04 & 0.031 & 0.04 & 0.046 & 0.006 & -0.005 & 0.009 & 0.014 \\
\hline Cons. Coef. & -9.806 & -72.087 & -62.285 & -75.664 & -83.216 & -7.808 & 13.755 & -13.991 & -27.622 \\
\hline Growth Rate & 2.01 & 9.67 & 7.52 & 9.74 & 11.25 & 1.40 & -1.06 & 2.19 & 3.28 \\
\hline
\end{tabular}

Note: *; coefficient is significant at the 0.05 level.

Table-3. The growth rate in cropped area, production and yield of commercial crops Conti...

\begin{tabular}{c|c|c|c|c|c|c}
\hline Crops & \multicolumn{3}{|c|}{ Castor } & \multicolumn{3}{c}{ Potato } \\
\hline Components & Area sown & Production & Yield & Area sown & Production & Yield \\
\hline Skewness & 0.347 & 0.654 & 0.057 & 0.15 & 0.38 \\
\hline No. of Obs. & 37 & 37 & 37 & 44 & 44 & 44 \\
\hline F-Value & $74.97^{*}$ & $24.93^{*}$ & $7.09^{*}$ & $792.32^{*}$ & $594.68^{*}$ & $0.93^{*}$ \\
\hline Prob>F & 0.000 & 0.000 & 0.012 & 0.000 & 0.000 & 0.34 \\
\hline$R^{2}$ & 0.682 & 0.416 & 0.168 & 0.951 & 0.936 & 0.022 \\
\hline Adj. $R^{2}$ & 0.673 & 0.399 & 0.145 & 0.95 & 0.934 & 0.002 \\
\hline TTF & 0.041 & 0.024 & -0.018 & 0.069 & 0.07 & 0.002 \\
\hline Cons. Coef. & -76.684 & -42.702 & 33.745 & -133.686 & -133.817 & -0.035 \\
\hline Growth Rate & 9.97 & 5.57 & -3.97 & 17.10 & 17.55 & 0.37 \\
\hline Nicficit
\end{tabular}

Note: *; coefficient is significant at the 0.05 level.

Table-3. The growth rate in cropped area, production and yield of commercial crops Conti...

\begin{tabular}{c|c|c|c|c|c|c}
\hline Crops & \multicolumn{3}{|c|}{ Groundnut } & \multicolumn{3}{c}{ Sesame } \\
\hline Components & Area sown & Production & Yield & Area sown & Production & Yield \\
\hline Skewness & 0.594 & 0.454 & 0.468 & 0.244 & 0.951 & 0.047 \\
\hline No. of Obs. & 44 & 44 & 44 & 44 & 44 & 44 \\
\hline F-Value & 0.36 & $4.16^{*} *$ & $5.73^{*} *$ & $69.34^{*}$ & $27.48^{*}$ & $4.31^{*} *$ \\
\hline Prob>F & 0.551 & 0.048 & 0.021 & 0.000 & 0.000 & 0.044 \\
\hline$R^{2}$ & 0.009 & 0.09 & 0.12 & 0.623 & 0.396 & 0.093 \\
\hline Adj. $R^{2}$ & 0.015 & 0.068 & 0.099 & 0.614 & 0.381 & 0.072 \\
\hline TTF & -0.001 & 0.016 & 0.017 & 0.029 & 0.042 & 0.012 \\
\hline Cons. Coef. & 9.395 & -24.85 & -34.277 & -53.15 & -79.302 & -25.972 \\
\hline Growth Rate & -0.22 & 3.79 & 4.02 & 6.99 & 10.12 & 2.91 \\
\hline Note: ${ }^{*} *$ coefficient is significant at the 0.01 level and *; coefficient is significant at the 0.05 level. &
\end{tabular}

Table-3. The growth rate in cropped area, production and yield of commercial crops Conti...

\begin{tabular}{c|c|c|c|c|c|c}
\hline Crops & \multicolumn{2}{|c|}{ Rapeseed \& Mustard } & \multicolumn{4}{c}{ Soybeans } \\
\hline Components & Area sown & Production & Yield & Area sown & Production & Yield \\
\hline Skewness & -0.065 & -0.398 & -0.717 & 0.726 & 0.571 & 0.31 \\
\hline No. of Obs. & 39 & 39 & 39 & 24 & 24 & 24 \\
\hline F-Value & $15.83^{*}$ & $38.32^{*}$ & $48.33^{*}$ & $21.84^{*}$ & $200.66^{*}$ & $36.05^{*}$ \\
\hline Prob $>F$ & 0.000 & 0.000 & 0.000 & 0.000 & 0.000 & 0.000 \\
\hline$R^{2}$ & 0.3 & 0.509 & 0.566 & 0.498 & 0.901 & 0.621 \\
\hline Adj. $R^{2}$ & 0.281 & 0.496 & 0.555 & 0.475 & 0.897 & 0.604 \\
\hline TTF & 0.021 & 0.048 & 0.027 & 0.095 & 0.266 & 0.17 \\
\hline Cons. Coef. & -36.525 & -90.752 & -54.164 & -187.133 & -530.03 & -339.601 \\
\hline Growth Rate & 4.96 & 11.75 & 6.46 & 24.46 & 84.65 & 47.80 \\
\hline Note: ${ }^{*}$ coefficient is significant at the 0.05 level. & & & &
\end{tabular}

Thus, the estimates specify the technological change will be useful to increase the cropped area, production and yield of cash crops in Gujarat. Furthermore, growth in cropped area, production and yield of cash crops were seemed positive. Here, the estimates clearly impose that cropped area, production and yield crops will increase as application of more technologies in agriculture sector of Gujarat. The influence of time trend factor $(T T F)$ on 
cropped area, total production and productivity of potato crop is given in Table 3. The R-square value was found 0.95 and 0.93 for area sown and production respectively for potato. Thus, the estimates infer that 95\% and 93\% variation in area sown and production of potato depend upon technological change. The regression coefficient of $T T F$ with area sown, production and yield of potato crop was seemed positive and statistically significant. Application of technology, therefore, would be useful to increase the production and yield of potato crop in Gujarat. The area shown and production may be increased by $17.10 \%$ and $17.35 \%$ respectively as $1 \%$ increase in application of technological change in farming of potato crop. The regression coefficient of TTF with area sown, total production and yield of oilseed crops is given in Table 3. The values of skewness for cropped area, production and yield of all oilseed crops were lie between -1 to +1 . Thus, time series of area sown, production and yield of all oilseed crops were normally distributed. The $R$-square showed that $63 \%$ and $40 \%$ variation in area sown and production of sesame; $30 \%, 51 \%$ and $57 \%$ variation in area sown, production and yield of rapeseed \& mustard; $50 \%$, $90 \%$ and $62 \%$ variation in area sown, production and yield of soybeans; and $93 \%, 86 \%$ and $49 \%$ variation in area sown, production and yield of cotton seed can be captured through Technological change. The regression coefficient of $T T F$ with area sown, production and yield of groundnut, sesame, rapeseed \& mustard, soybean and castor seed crops were appeared positive (except area sown of groundnut crop) and statistically significant. Thus, the results show that application of technologies would be useful to increase the cropped area, total production and yield of groundnut, sesame, rapeseed \& mustard, soybean and castor seed crops in Gujarat. Furthermore, growth of cropped area, production and yield of oilseed crops (except area sown of groundnut crop) were positive. Therefore, the empirical results provide evidence that the production and yield of these crops would be beneficial due to use of technologies in farming of oilseed crops in Gujarat.

\subsection{Growth Rate of Food-grain Crops}

The regression coefficient of technological change with cropped area, production and yield of food-grain crops is presented in the Table 4 . The values of $R$-square shows that $74 \%$ and $62 \%$ variation in area sown and production, respectively of rice; $34 \%$ and $48 \%$ variation in area sown and production, respectively of Arhar, $95 \%$ and $40 \%$ variation in area sown and production of maize, $37 \%$ and $32 \%$ variation in area sown and production of gram; $26 \%$, $51 \%$ and $72 \%$ variation in area sown, production and yield of wheat; $91 \%, 54 \%$ and $65 \%$ variation in area sown, production and yield of Jowar; and $88 \%$ and $68 \%$ variation in area sown and production of ragi were fluctuated due to application of technological change in farming of these crops. The regression coefficient of $T T F$ with area sown, production and yield of rice, arhar, maize, gram and wheat crops were seemed positive and statistically significant. Thus, the estimates infer that usage of technologies in farming would be useful to increase area sown, production and yield of most food-grain crops. Furthermore, the growth rate for these crops was also seemed positive and statistically significant. However, growth of area sown, production and productivity of bajra, jowar and ragi crops were found negative. Thus, technological change has negative impact on farming of bajra, jowar and ragi crops.

Table-4. The growth of cropped area, production and yield of food-grain crops.

\begin{tabular}{c|c|c|c|c|c|c}
\hline Crops & \multicolumn{3}{|c|}{ Rice } & \multicolumn{3}{c}{ Arhar } \\
\hline Components & Area sown & Production & Yield & Area sown & Production & Yield \\
\hline Skewness & 0.104 & 0.449 & -0.082 & -0.667 & -0.411 & 0.241 \\
\hline No. of Obs. & 44 & 44 & 44 & 44 & 44 & 44 \\
\hline F-Value & $125.34^{*}$ & $68.42^{*}$ & $24.79^{*}$ & $22.04^{*}$ & $39.32^{*}$ & $27.31^{*}$ \\
\hline Prob $>F$ & 0.000 & 0.000 & 0.000 & 0.000 & 0.000 & 0.000 \\
\hline$R^{2}$ & 0.749 & 0.62 & 0.371 & 0.344 & 0.484 & 0.394 \\
\hline Adj. $R^{2}$ & 0.743 & 0.611 & 0.356 & 0.329 & 0.471 & 0.38 \\
\hline TTF & 0.013 & 0.032 & 0.019 & 0.023 & 0.04 & 0.017 \\
\hline Cons. Coef. & -19.011 & -56.945 & -37.932 & -40.614 & -74.216 & -33.613 \\
\hline Growth Rate & 2.98 & 7.63 & 4.51 & 5.48 & 9.61 & 3.92 \\
\hline Note: *; coefficient is significant at the 0.05 level.
\end{tabular}


Table-4. The growth of cropped area, production and yield of food-grain crops Conti...

\begin{tabular}{c|c|c|c|c|c|c}
\hline Crops & \multicolumn{3}{|c|}{ Maize } & \multicolumn{3}{c}{ Bajra } \\
\hline Components & Area sown & Production & Yield & Area sown & Production & Yield \\
\hline Skewness & 0.263 & 0.179 & -0.341 & 0.233 & -0.209 & 0.594 \\
\hline No. of Obs. & 44 & 44 & 44 & 44 & 44 & 44 \\
\hline F-Value & $714.78^{*}$ & $27.99^{*}$ & $4.24^{* *}$ & $322.7^{*}$ & 1.06 & $32.74^{*}$ \\
\hline Prob $>F$ & 0.000 & 0.000 & 0.046 & 0.000 & 0.309 & 0.000 \\
\hline$R^{2}$ & 0.945 & 0.4 & 0.092 & 0.885 & 0.025 & 0.438 \\
\hline Adj. $R^{2}$ & 0.943 & 0.386 & 0.07 & 0.882 & 0.001 & 0.425 \\
\hline TTF & 0.017 & 0.027 & 0.011 & -0.021 & -0.003 & 0.018 \\
\hline Cons. Coef. & -27.389 & -48.35 & -21.112 & 49.914 & 13.926 & -35.944 \\
\hline Growth Rate & 3.92 & 6.48 & 2.48 & -4.83 & -0.79 & 4.24 \\
\hline Note: ${ }^{* *} ;$ coefficient is significant at the 0.01 level and *; coefficient is significant at the 0.05 level.
\end{tabular}

Table-4. The growth of cropped area, production and yield of food-grain crops Conti...

\begin{tabular}{c|c|c|c|c|c|c}
\hline Crops & \multicolumn{5}{|c|}{ Gram } & \multicolumn{3}{c}{ Wheat } \\
\hline Components & Area sown & Production & Yield & Area sown & Production & Yield \\
\hline Skewness & 0.704 & 0.29 & 0.131 & 0.97 & 0.531 & 0.218 \\
\hline No. of Obs. & 44 & 44 & 44 & 44 & 44 & 44 \\
\hline F-Value & $24.28^{*}$ & $20.04^{*}$ & 0.83 & $14.44^{* *}$ & $44.24^{*}$ & $106.7^{*}$ \\
\hline Prob $>F$ & 0.000 & 0.000 & 0.368 & 0.001 & 0.000 & 0.000 \\
\hline$R^{2}$ & 0.366 & 0.323 & 0.019 & 0.256 & 0.513 & 0.718 \\
\hline Adj. $R^{2}$ & 0.351 & 0.307 & 0.004 & 0.238 & 0.501 & 0.711 \\
\hline TTF & 0.028 & 0.034 & 0.007 & 0.014 & 0.03 & 0.016 \\
\hline Cons. Coef. & -50.846 & -64.449 & -13.479 & -21.875 & -52.409 & -30.594 \\
\hline Growth Rate & 6.62 & 8.26 & 1.53 & 3.33 & 7.14 & 3.69 \\
\hline Note: **; coefficient is significant at the 0.01 level and *; coefficient is significant at the 0.05 level. & &
\end{tabular}

Table-4. The growth of cropped area, production and yield of food-grain crops Conti...

\begin{tabular}{c|c|c|c|c|c|c}
\hline Crops & \multicolumn{3}{|c|}{ Jowar } & \multicolumn{3}{c}{ Ragi } \\
\hline Components & Area sown & Production & Yield & Area sown & Production & Yield \\
\hline Skewness & 0.159 & 0.632 & 0.943 & 0.239 & 0.655 & 0.108 \\
\hline No. of Obs. & 44 & 44 & 44 & 44 & 44 & 44 \\
\hline F-Value & $437.73^{*}$ & $48.61^{*}$ & $76.35^{*}$ & $303.91^{*}$ & $86.87^{*}$ & $3.71^{*} * *$ \\
\hline Prob $>F$ & 0.000 & 0.000 & 0.000 & 0.000 & 0.000 & 0.061 \\
\hline$R^{2}$ & 0.913 & 0.537 & 0.645 & 0.879 & 0.674 & 0.081 \\
\hline Adj. $R^{2}$ & 0.91 & 0.526 & 0.637 & 0.876 & 0.666 & 0.059 \\
\hline TTF & -0.067 & -0.033 & 0.034 & -0.035 & -0.029 & 0.005 \\
\hline Cons. Coef. & 139.603 & 71.101 & -68.5 & 72.356 & 61.415 & -10.902 \\
\hline Growth Rate & -14.3 & -7.29 & 8.18 & -7.66 & -6.51 & 1.25 \\
\hline Note: * coefficient is significant at the 0.05 level and ***; coefficient is significant
\end{tabular}

Note: *; coefficient is significant at the 0.05 level and ***; coefficient is significant at the 0.10 level.

\section{IMPACT OF TECHNOLOGICAL CHANGE ON YIELD OF FOOD-GRAIN AND COMMERCIAL CROPS}

\subsection{Correlation Coefficients of Explanatory Variables with Yield of Crops}

The correlation coefficient of yield of crops with $T T F$ and explanatory variable is given in Table 5. The correlation coefficient of TTF with yield of all crops were found positive and statistically significant. Thus, the estimates show that yield of most crops are expected to increase as increase in technological change in cultivation. Previous studies such as Kumar (2015); Kumar et al. (2015a); Kumar et al. (2017); Jyoti and Singh (2020) have also reported positive impact of technological change on productivity of commercial and cash crops in India. The estimates can be justified that use of technological change such as irrigated area, water irrigation technologies, farm land management practices, green fertilizer, high yielding seeds, and other have positive impact on agricultural production. Hence, application of technological change in agricultural sector will be useful to increase the yield of 
crops in Gujarat. Arable area is a prime input for agricultural production. Therefore, correlation coefficient of area sown with yield of all crops (except bajra, jowar and ragi) were seemed positive and statistically significant. The estimates indicate that yield of these crops may increase as increase in area sown. However, previous studies such as Kumar (2015); Kumar et al. (2015b); Kumar et al. (2017); Singh et al. (2017); Singh and Sharma (2018); Jyoti and Singh (2020) have argued land productivity of crop may be declined as increase in area sown due to applicability of law of diminishing return in agriculture sector. Hence, up to a certain extent yield of a specific crop will increase as increase in area sown, thereafter, it may be declined in agricultural sector. The correlation coefficient of irrigated area with yield of most crops (except jowar and ragi) were appeared positive and statistically significant. Hence, the estimates are purposed that yield of food-grain and cash crops will improve as increase in irrigated area. This result is reliable with previous revisions such as Joshi (2012); Kumar and Sharma (2014); Birthal et al. (2014); Kumar (2015); Kumar et al. (2016); Kumar et al. (2017); Jyoti and Singh (2020); Kumar et al. (2020). Here, it can be argued that technological change will be useful to increase water conservation to increase the irrigation condition in cultivation. The correlation coefficient of application of fertilizer per hectare arable land with crops (except tobacco crop) were found positive and statistically significant. The estimates indicate that application of fertilizer will be effective to increase the crop productivity. However, extensive use of fertilizer may be caused to reduce soil quality and fertility; therefore, it is projected that crop productivity will be declined (Jyoti \& Singh, 2020; Kumar., 2015; Kumar et al., 2015a; Kumar et al., 2017; Singh. et al., 2017). Thus, farmer must use minimum quantity of fertilizer in cultivation.

Table-5. Correlation coefficient of yield of crops with explanatory variables.

\begin{tabular}{|c|c|c|c|c|c|c|c|}
\hline Crops & TTF & AS & GIA & FAPHL & ALPHL & LRPPHL & AARF \\
\hline Sugarcane & $0.301^{*}$ & $0.270^{*}$ & 0.180 & 0.239 & 0.198 & $0.278^{*}$ & $0.246^{*}$ \\
\hline Tobacco & 0.018 & 0.005 & 0.098 & -0.017 & -0.155 & -0.027 & $0.548^{* * *}$ \\
\hline Castor & $0.534^{* * *}$ & $0.523^{* *}$ & $0.574^{* *}$ & $0.565^{* * *}$ & $0.488^{*} *$ & $0.509^{* *}$ & $0.546^{* * *}$ \\
\hline Rice & $0.815^{* *}$ & $0.784^{* *}$ & $0.8411^{* *}$ & $0.775^{* * *}$ & $0.711^{* *}$ & $0.772 * *$ & 0.237 \\
\hline Maize & $0.384^{* * *}$ & $0.359^{* *}$ & $0.357^{* *}$ & $0.349^{* * *}$ & $0.358^{* * *}$ & $0.361^{* *}$ & -0.122 \\
\hline Bajra & $0.776^{* *}$ & $-0.747^{* *}$ & $0.476^{* *}$ & $0.710^{* * *}$ & $0.702^{* *}$ & $0.736^{* *}$ & 0.042 \\
\hline Gram & $0.539^{* * *}$ & $0.666^{* *}$ & $0.663^{* *}$ & $0.571^{* * *}$ & $0.409^{* *}$ & $0.487 * *$ & 0.015 \\
\hline Wheat & $0.886^{* * *}$ & $0.745^{* *}$ & $0.859^{* *}$ & $0.854^{* * *}$ & $0.808^{* * *}$ & $0.854^{* *}$ & $0.263^{*}$ \\
\hline Groundnut & $0.537^{* *}$ & 0.017 & $0.611^{* *}$ & $0.460^{* *}$ & $0.469^{*} *$ & $0.509^{* *}$ & 0.062 \\
\hline Sesamum & $0.425^{* *}$ & $0.402^{* *}$ & $0.528^{* *}$ & $0.349^{* *}$ & $0.415^{* *}$ & $0.407 * *$ & -0.064 \\
\hline Rapeseed \& Mustard & $0.801^{* *}$ & $0.349^{*}$ & $0.776^{* *}$ & $0.732^{* * *}$ & $0.710^{* * *}$ & $0.765^{* *}$ & 0.028 \\
\hline Soyabeans & $0.642^{*} *$ & $0.348^{* *}$ & $0.594^{* *}$ & $0.625^{* * *}$ & $0.629^{* *}$ & $0.633^{* *}$ & 0.179 \\
\hline
\end{tabular}

Furthermore, farmers may opt organic farming to increase crop productivity in agricultural sector (Hazarika et al., 2013). Human power is also a crucial input in agricultural production activities. Thus, correlation coefficient of application of agricultural labour on per hectare land with yield of most crops (except tobacco crop) were appeared positive and statistically significant. Thus, the estimate specify that yield of most crops was positively associated with application of agricultural workers. However, Kumar et al. (2016) have reported that crop yield is likely to be declined as additional use of agriculture workers in Indian agriculture. The correlation coefficient of literate rural population on per hectare land with yield of all crops (except tobacco) was seemed positive. Hence, the estimates imply that participation of literate population will be useful to increase the crop productivity in agriculture sector of Gujarat. Literate farmers have more skills and knowledge on agricultural technologies and other inputs, and 
appropriate way to use of fertilizer and irrigation in cultivation. Literate farmers also have the better understanding on appropriate time of seed planning, irrigation, and selection of crops for cultivation. Therefore, yield of crops may increase as increase in skills, technological ability and knowledge of farmers. Here, it is proposed that agricultural extension offices, agricultural development agencies and agricultural universities should organize regular training for farmers to increase their understanding on new technologies and agricultural inputs. The rainfall is highly useful to recharge the water in ground, thus, it has a significant role to meet the irrigation requirement of a particular crop. Accordingly, yield of crop improves as increase in annual rainfall. The correlation coefficient of annual actual rainfall with yield of all crops (except maize, ragi and sesamum) were observed positive and statistically significant.

\subsection{Regression Coefficients of Explanatory Variables with Yield of Crops}

The regression results which assess the influence of yield of food-grain and cash crop is given in Table 6 . The $F$-values for all crops were found statistically significant. Thus, the estimates imply that Cobb-Douglas production model provide a best result. The $R^{2}$ values for cotton, tobacco, castor, rice, arhar, bajra, gram, wheat, jowar and rapesed\&mustard crops were found $0.84,0.81,0.80,0.76,0.72,0.75,0.74,0.84,0.75$ and 0.73 , respectively. Therefore, the estimates indicate that $84 \%, 81 \%, 80 \%, 76 \%, 72 \%, 75 \%, 74 \%, 0.84 \% 75 \%$ and $73 \%$ variation in yields of these crops depend upon technological change, area sown, used of various inputs on per hectare land, literate rural population on per hectare land and annual actual rainfall. Yield of sugarcane and maize crops can be explained by $58 \%$ and $25 \%$, respectively through undertaken explanatory variables. Therefore, it can be concluded that variation in yield of sugarcane and maize crops also depends upon another agriculture inputs such as climatic conditions, geographical location, soil and seed quality, farm management practices, pesticides, sowing time of seed, field preparation, irrigation methods, farmer experience, appropriate marketing, appropriate price of production, government policies, financial availability, banking facilities and others (Jyoti \& Singh, 2020; Kumar, 2015; Kumar et al., 2017; Kumar et al., 2015b).

Table-6. Regression coefficients of explanatory variables with yield of crops.

\begin{tabular}{|c|c|c|c|c|c|c|c|c|}
\hline Crops & Cotton & Sugarcane & Tobacco & Castor & Potato & Groundnut & Sesamum & $\begin{array}{c}\text { Rapeseed\& } \\
\text { Mustard }\end{array}$ \\
\hline No. of obs. & 47 & 47 & 21 & 41 & 47 & 47 & 47 & 41 \\
\hline F-Value & $29.81^{*}$ & $7.62^{*}$ & $8.23^{*}$ & $18.84^{*}$ & $2.65^{* *}$ & $11.81^{*}$ & $5.06^{*}$ & $12.97^{*}$ \\
\hline$R^{2}$ & 0.8425 & 0.5776 & 0.8159 & 0.7998 & 0.3222 & 0.6795 & 0.4757 & 0.7334 \\
\hline$A d j . R^{2}$ & 0.8143 & 0.5018 & 0.7167 & 0.7574 & 0.2006 & 0.622 & 0.3816 & 0.6769 \\
\hline$T T F$ & $0.067^{*}$ & $-0.015^{*}$ & 0.049 & -0.028 & $0.028^{* *}$ & $0.097^{*}$ & $0.067^{* * * *}$ & $0.012^{* *}$ \\
\hline $\log A S$ & -0.672 & -0.11 & 0.09 & 0.496* & -0.049 & -0.3 & -0.064 & 0.216 \\
\hline $\log G I A$ & $1.045^{* *}$ & 0.1 & -0.47 & 0.49 & 0.11 & $2.255^{* *}$ & $1.342^{*}$ & -0.5 \\
\hline $\log F A P H L$ & 0.068 & -0.055 & -0.63 & -0.242 & 0.031 & $-1.638^{*}$ & 0.098 & -0.217 \\
\hline $\log A L P H L$ & -0.957 & -2.382 & -0.037 & -0.158 & -0.392 & -1.26 & 1.956 & -3.679 \\
\hline $\log L R P P H L$ & -1.83 & 2.2 & -0.48 & 0.75 & -0.69 & -0.98 & $-5.782^{*}$ & 3.72 \\
\hline $\log A A R F$ & 0.067 & $0.019^{* *}$ & $0.646^{*}$ & $0.663^{*}$ & 0.024 & 0.017 & -0.014 & $-0.066^{* *}$ \\
\hline Con. Coef. & $-130.49^{*}$ & 41.196 & -92.787 & 57.795 & $-45.51^{* * * *}$ & $-191.245^{*}$ & $-131.05^{* *}$ & -19.137 \\
\hline
\end{tabular}

The regression coefficient of $T T F$ with yield of cotton, tobacco, rice, arhar, maize, bajra, gram, wheat, jowar, ragi, potato, groundnut, sesamum, rapeseed \& mustard and soyabean were found positive and statistically significant. Thus, the estimates imply that yield of these crops increases as increase in use of technological change in cultivation. The regression coefficients of area sown with yield of cotton, sugarcane, tobacco, rice, arhar, bajra, wheat, jowar, ragi, potato, groundnut and sesamum crops were seemed negative. Thus, the estimates specify that yield of these crops will be decreased as increase in the area sown of aforementioned crops. The estimate is similar with previous studies such as Kumar (2015); Kumar et al. (2015a); Kumar et al. (2017); Jyoti and Singh (2020) which 
have reported negative impact of area shown on yield of food-grain and cash crops in India. These studies have also claimed that productivity of crop is likely to be decreased as increase in cropped area due to applicability of law of diminishing return in agriculture sector. The regression coefficient of yield of most crops (except tobacco and maize) with irrigated area was appeared positive. Hence, the estimates infer that policy makers and farmer should develop more water resources through technological change to meet the water irrigation requirement in agriculture sector (Jyoti \& Singh, 2020; Kumar, 2015; Kumar et al., 2017; Kumar et al., 2015b).

Table-6. Regression coefficients of explanatory variables with yield of crops Conti...

\begin{tabular}{|c|c|c|c|c|c|c|c|c|c|}
\hline Crops & Soyabean & Rice & Arhar & Maize & Bajra & Gram & Wheat & Jowar & Ragi \\
\hline No. of obs. & 47 & 47 & 47 & 47 & 47 & 47 & 47 & 47 & 47 \\
\hline F-Value & $5.32^{*}$ & 17.38* & $14.27^{*}$ & $1.84^{* * * *}$ & $16.88^{*}$ & $15.82^{*}$ & 29.03* & $16.85^{*}$ & $2.84^{*}$ \\
\hline$R^{2}$ & 0.4883 & 0.7573 & 0.7192 & 0.2481 & 0.7519 & 0.7395 & 0.839 & 0.7515 & 0.338 \\
\hline Adj. $R^{2}$ & 0.3964 & 0.7137 & 0.6688 & 0.1132 & 0.7073 & 0.6927 & 0.8101 & 0.7069 & 0.2191 \\
\hline$T T F$ & -0.009 & $0.034 * *$ & $0.038 * *$ & $0.050^{* * *}$ & 0.066* & $0.062 *$ & 0.008 & 0.088* & 0.003 \\
\hline $\log A S$ & $-0.210^{* *}$ & -2.066 & -0.268 & 1.059 & -0.22 & $0.137^{* * *}$ & -0.113 & -0.227 & $-1.332^{*}$ \\
\hline $\log G I A$ & 0.84 & 1.88 & $0.476^{* * * *}$ & -0.56 & $1.056^{*}$ & 0.09 & 0.23 & $0.589^{* * * *}$ & $1.511^{*}$ \\
\hline $\log F A P H L$ & 0.016 & -0.729 & $0.374 * *$ & 0.038 & -0.124 & 0.034 & 0.014 & 0.197 & -0.239 \\
\hline $\log A L P H L$ & -2.901 & -1.743 & -0.485 & 0.804 & 0.582 & 0.318 & 0.112 & $3.487^{*}$ & $1.596^{* * *}$ \\
\hline $\log L R P P H L$ & 2.77 & 0.31 & $-1.860^{* *}$ & -1.96 & $-2.213^{* *}$ & $-2.394^{*}$ & -0.15 & $-4.082^{*}$ & $-1.614^{* * *}$ \\
\hline $\log A A R F$ & 0.038 & $-0.014 * *$ & 0.297 * & -0.104 & 0.006 & -0.043 & 0.008 & 0.054 & $-0.125^{* *}$ \\
\hline Con. Coef. & 23.599 & -53.635 & -72.45 *** & -98.631 & $-128.7 \mathrm{O}^{*}$ & $-117.85^{*}$ & -8.517 & $-169.21^{*}$ & 4.75 \\
\hline
\end{tabular}

Note: **; coefficient is significant at the 0.01 level, *; coefficient is significant at the 0.05 level and ***; coefficient is significant at the 0.10 level.

The influence of fertilizer on sugarcane, tobacco, castor, rice, bajra, ragi, groundnut and rapeseed \& mustard were appeared negative. Thus, the estimate shows that application of fertilizer may not be beneficial to increase the yield of these crops. Since, extensive use of fertilizer may be caused to reduce soil quality and fertility in long term. Thus, productivity of crop is likely to decrease as increase in extensive application of fertilizer in crop cultivation. Kumar (2015); Kumar et al. (2015a); Kumar et al. (2015b); Kumar et al. (2016); Kumar et al. (2017); Jyoti and Singh (2020) have also observed negative impact of application of fertilizer on food-grain and commercial crops in Indian agriculture. The regression coefficient of agricultural labour on per hectare land with yield varied across crops. Thus, the impact of agricultural labour on yield of food-grain and commercial crops varied in Gujarat. Therefore, the estimates indicate that yield of cotton, sugarcane, tobacco, castor, rice, arhar, potato, groundnut and sesamum crops may decrease as marginal use of agricultural labour in agriculture sector. The estimates can be justified that additional use of agricultural labour may not be effective to increase the yield of crops due to presence of law of diminishing return in agriculture sector (Kumar et al., 2016). Similar justification on the relationship of agricultural productivity with human resource was also provided by Kumar et al. (2016) in context of Indian agriculture.

Literate person does not want to be involved in agricultural production activities to sustain their livelihood. Therefore, the regression coefficient of literate rural population with yield of most crops were found negative and statistically significant. However, arrangement of training facilities for farmers will be beneficial for them to upsurge their sympathetic on technological application, irrigation requirement, quantity of fertilizer and pesticides, selection of crops for cultivation, seed quality and other inputs in agriculture sector. Thus, role of literate farmers would be valuable to increase crop yield in agriculture sector. Annual actual rainfall shows a negative impact on yield of rice, maize, gram, ragi, sesamum and rapeseed \& mustard crop in Gujarat. Previous studies such as Kumar and Sharma (2014); Kumar, Sharma, and Ambrammal (2014); Kumar (2015); Kumar et al. (2016); Kumar et al. (2017); Singh and Sharma (2018); Kumar et al. (2020); Jyoti and Singh (2020); Singh and Jyoti (2021a); Singh and Jyoti (2021b) have also observed negative impact of rainfall in Indian agriculture sector. In contrary, yield of cotton, sugarcane, tobacco, castor, arhar, bajra, wheat, jowar, potato, groundnut and soyabean crops increase due to increase on actual annual rainfall in Gujarat. 


\section{CONCLUSION AND POLICY IMPLICATIONS}

The results based on growth rate model show that technological change is useful to increase the production activities of commercial and food-grain crops in Gujarat. The estimates also indicate that use of technologies would be helpful to increase the growth of area, production and yield of crops in Gujarat. Thus, farming community should focus to use more technologies in cultivation to get better benefit from agricultural production activities. Furthermore, technological change is useful to increase the growth of cropped area, production and yield of foodgrain and commercial crops in Gujarat. As the regression coefficient of time trend factor with area sown, production and yield were seemed positive for all crops (except bajra, jowar and ragi). Thus, the estimates indicate that use of technologies in cultivation would be helpful to sustain the agricultural productivity in Gujarat. Cropped area, production and yield of cotton, sugarcane, castor, potato, rice, arhar, maize, gram and wheat crops have positive growth rate during 1971-2013 due to technological change in Gujarat. The empirical results also show that yield of rice, arhar, maize, bajra, gram, wheat, jowar and ragi, cotton, sugarcane, tobacco, castor, potato, groundnut, sesame, rapeseed \& mustard and soyabean crops will increase as use of technologies in agricultural sector of Gujarat. The results also infer that yield of most crop will be improved as increase in irrigated area. Furthermore, farming community should use optimum quantity of fertilizer to maintain soil quality and fertility, and yield of food-grain and cash crop in Gujarat. There also must be planning of regular training facilities for farmers to increase their understanding on application of technologies, irrigation requirement and other inputs in agriculture sector of Gujarat. Time trend factor, area sown, irrigation facilities, consumption of fertilizer and agricultural workforce on per hectare land, ratio of rural literate population with gross sown area and actual annual rainfall have different impact on yield of food-grain and cash crops. Thus, there is requirement to formulae a crop specific policy to reduce to negative impact of inputs in agriculture sector of Gujarat. Furthermore, there are also needs to create appropriate Agri-start-ups ecosystem in order to increase the application of technology in Indian agricultural sector. As agricultural R\&D spending have a greater contribution towards creation of technology, thus it is essential to increase public spending in this sector research and development. However, at global level the public investment in agricultural $\mathrm{R} \& \mathrm{D}$ has slowed and the share of private sector is increased. Research programs to improve agricultural technology accordingly require a high degree of targeting to local environmental conditions. The role of agricultural $\mathrm{R} \& \mathrm{D}$ has become an important to solve several problems of Indian agriculture. R\&D generates technologies and passes them to farmers. It would be helpful to discover genetic modification of seeds which have high yielding capacity with minimum use of agricultural resources and agro-chemicals. Crop-breeding and genetically modified crops can be aligned to well-researched genetic engineering and Agri-biotechnology. Subsequently, crop yield of food-grain and cash crops are expected to be increase due to application of technology in Indian agricultural sector. Also, India requires infusion of demand-driven, affordable and user-friendly technologies in both farm and non-farm sectors. It would be useful to increase the intension of farmers to adopt new technology in agricultural sector in India. There are also other challenges who will bear the risk if a technology could not provide a significant benefit to farmers. Local development stakeholder needs to provide technical support to the farmers to increase agriculture development. As Indian agriculture requires three pillars such as knowledge, infrastructure and robust mechanism. There is essential to increase the understanding of farmers towards technology know-how and do-how about the latest agriculture technology, plant protection, soil health, climate resilient agriculture, conservation of natural resources, livestock production, farm machinery, use of ICTs and sustainable livelihood security option to sustainable agricultural development in India. India needs to adopt biotechnological tools to changing environmental conditions, increase food production, food security, and nutritional security in India.

Funding: This study received no specific financial support.

Competing Interests: The authors declare that they have no competing interests.

Acknowledgement: Both authors contributed equally to the conception and design of the study. 


\section{REFERENCES}

Abdullahi, H. S., Mahieddine, F., \& Sheriff, R. E. (2015). Technology impact on agricultural productivity: A review of precision agriculture using unmanned Aerial vehicles. Paper presented at the International Conference on Wireless and Satellite Systems, Bradford, 2015, UK: Springer.

Basant, R. (1987). Agricultural technology and employment in India: A survey of recent research. Economic and Political Weekly, 22(32), 1348-1364.

Basavaraja, H., Mahajanashetti, S., \& Sivanagaraju, P. (2008). Technological change in paddy production: A comparative analysis of traditional and SRI methods of cultivation. Indian Journal of Agricultural Economics, 63(902-2016-67976), 629-640.

Birthal, P. S., Khan, T., Negi, D. S., \& Agarwal, S. (2014). Impact of climate change on yields of major food crops in India: Implications for food security. Agricultural Economics Research Review, 27(2), 145-155.Available at: https://doi.org/10.5958/0974-0279.2014.00019.6.

Chakrabarti, H. K., Bagchi, K. K., \& A, B. (2002). Impact of new agriculture technology on economic conditions of agricultural labourers: A case study of two villages of West Bengal. Labour and Development, 8(1 \& 2), 62-89.

Chandrashekar, H. M. (2010). Changing scenario of organic farming in India: An overview. International NGO Journal, 5(2), 034039.

Davari, M., Ram, M., Tewari, J., \& Kaushish, S. (2010). Impact of agricultural practice on ecosystem services. International Journal of Agronomy and Plant Production, 1(1), 11-23.

Deb, U., Mandal, M., \& Dey, M. (1991). Impact of new technology on production variability in Bangladesh agriculture. Bangladesh Journal of Agricultural Economics, 14(454-2016-36766), 27-50.

Desai, B. M. (1994). Contributions of institutional credit, self-finance and technological change to agricultural growth in India. Indian Journal of Agricultural Economics, 49(902-2018-3308), 457-476.

Eyhorn, F., Ramakrishnan, M., \& Mäder, P. (2011). The viability of cotton-based farming systems in India. International Journal of Agricultural Sustainability, 5(1), 23-35.Available at: https://doi.org/10.1080/14735903.2007.9684811.

Eyhorn, F., van den Berg, M., Decock, C., Maat, H., \& Srivastava, A. (2018). Does organic farming provide a viable alternative for smallholder rice farmers in India? Sustainability, 1O(12), 1-15.Available at: https://doi.org/10.3390/su10124424.

Forster, D., Andres, C., Verma, R., Zundel, C., Messmer, M. M., \& Mäder, P. (2013). Yield and economic performance of organic and conventional cotton-based farming systems-results from a field trial in India. PloS One, 8(12), e81039.Available at: https://doi.org/10.1371/journal.pone.0081039.

Gebeyehu, M. G. (2016). The impact of technology adoption on agricultural productivity and production risk in Ethiopia: Evidence from rural Amhara household survey. Open Access Library Journal, 3(2), 1-14.Available at: https://doi.org/10.4236/oalib.1 102369.

Ghadiryanfar, M., Keyhani, A., Akram, A., \& Rafiee, S. (2009). The effect of tractor supply in Iran agriculture from a macro plan point of view. Research in Agricultural Engineering, 55(3), 121-127.Available at: https://doi.org/10.17221/28/2008-rae.

Hazarika, S., Manoj, K., Thakuria, D., \& Bordoloi, L. (2013). Organic Farming: Reality and concerns. Indian Journal of Hill Farming, 26(2), 88-97.

Joshi, S. (2012). Role of science and technology for agricultural revival in India. World Journal of Science, Technology and Sustainable Development, 9(2), 108-119.Available at: https://doi.org/10.1 108/20425941211244261.

Jyoti, B., \& Singh, A. K. (2020). Projected sugarcane yield in different climate change scenarios in Indian states: A state-wise panel data exploration. International Journal of Food and Agricultural Economics (IJFAEC), 8(1 128-2020-1797), 343-365.

Kannan, E. (2011). Trends in India's agricultural growth and its determinants. Asian Journal of Agriculture and Development, 8(1362-2016-107708), 79-99.

Kapur, R. (2018). Usage of technology in the agricultural sector. Acta Scientific Agriculture, 2(6), 78-84.

Khan, A., \& Anwar, T. (2009). Is there any role of technological inputs? A district-wise analysis of output differential in crop sector. The Pakistan Development Review, 47(4), 925-946.Available at: https://doi.org/10.30541/v47i4iipp.925-946. 
Kumar, K. K., Rupa, K. K., Ashrit, R., Deshpande, N., \& Hansen, J. W. (2004). Climate impacts on Indian agriculture. International Journal of Climatology: A Journal of the Royal Meteorological Society, 24(11), 1375-1393.

Kumar, A. (2015). Effect of climatic factors on agricultural productivity and food security in India: An econometric analysis. PhD Thesis, Indian Institute of Technology Indore, India.

Kumar, A., Sharma, P., \& Ambrammal, S. K. (2015a). Climatic effects on sugarcane productivity in India: A stochastic production function application. International Journal of Economics and Business Research, 10(2), 179-203.Available at: https://doi.org/10.1504/ijebr.2015.070984.

Kumar, A., Ahmad, M. M., \& Sharma, P. (2017). Influence of climatic and non-climatic factors on sustainable food security in India: A statistical investigation. International Journal of Sustainable Agricultural Management and Informatics, 3(1), 130.Available at: https://doi.org/10.1504/ijsami.2017.082917.

Kumar, K. K. (2011). Climate sensitivity of Indian agriculture: Do spatial effects matter? Cambridge Journal of Regions, Economy and Society, 4(2), 22 1-235.Available at: https://doi.org/10.1093/cjres/rsro04.

Kumar, A., \& Sharma, P. (2014). Climate change and sugarcane productivity in India: An empirical analysis. Journal of Social and Development Sciences, 5(2), 111-122.Available at: https://doi.org/10.22610/jsds.v5i2.811.

Kumar, A., Sharma, P., \& Joshi, S. (2015b). Effects of climatic factors on agricultural productivity in India: A state-wise panel data analysis. International Journal of Basic and Life Sciences, 1(1), 48-67.

Kumar, A., Sharma, P., \& Joshi, S. (2016). Assessing the impacts of climate change on land productivity in Indian crop agriculture: An evidence from panel data analysis. Journal of Agricultural Science and Technology, 18(1), 1-13.

Kumar, A., Singh, B., \& Sharma, P. (2020). Assessing the climate change impact on rice and wheat production in Uttar Pradesh and Haryana states of India. Climate Change, 6(21), 74-93.

Kumar, A., Sharma, P., \& Ambrammal, S. K. (2014). Climatic effects on food grain productivity in India. Journal of Studies in Dynamics and Change, 1(1), 38-48.

Mittal, S., \& Tripathi, G. (2009). Role of mobile phone technology in improving small farm productivity 1. Agricultural Economics Research Review, 22(1), 451-459.

Pandey, R., Crawford Jr, T., \& Maranville, J. (2002). Agriculture intensification and ecologically sustainable land use in Niger: A case study of evolution of intensive systems with supplementary irrigation. Journal of Sustainable Agriculture, 20(3), 3355.Available at: https://doi.org/10.1300/j064v20n03_05.

Pasa, R. B. (2017). Technological intervention in agriculture development. Nepalese Journal of Development and Rural Studies, 14(1-2), 86-97.Available at: https://doi.org/10.3126/njdrs.v 14i1-2.19652.

Patil, S., Reidsma, P., Shah, P., Purushothaman, S., \& Wolf, J. (2014). Comparing conventional and organic agriculture in Karnataka, India: Where and when can organic farming be sustainable? Land use Policy, 37, 40-51.Available at: https://doi.org/10.1016/j.landusepol.2012.01.006.

Pattnaik, I., \& Shah, A. (2015). Trends and decomposition of agricultural growth and crop output in Gujarat: Recent evidence. Indian Journal of Agricultural Economics, 70(902-2016-68377), 182-197.

Pingali, P., Aiyar, A., Abraham, M., \& Rahman, A. (2019). Agricultural technology for increasing competitiveness of small holders. In Transforming food systems for a rising India (pp. 215-240). Cham: Palgrave Macmillan.

Rao, N. (2007). A framework for implementing information and communication technologies in agricultural development in India. Technological Forecasting and Social Change, 74(4), 491-518.Available at: https://doi.org/10.1016/j.techfore.2006.02.002.

Reddy, Y. S., Roy, S., \& Tiwari, S. K. (2014). New technologies in vegetable production. Kurukshetra A Journal on Rural Development, 62(8), 20-23.

Saurabh, G. K. (2016). Economic impact of agriculture technology in India (with special reference to Bihar). PhD Thesis, Department of Applied Business Economics, Faculty of Commerce, Dayalbagh Educational Institute (Deemed University) Dayalbagh, Agra. 
Shabbir, M. S., \& Yaqoob, N. (2019). The impact of technological advancement on total factor productivity of cotton: A comparative analysis between Pakistan and India. Journal of Economic Structures, 8(1), 1-16.Available at: https://doi.org/10.1186/s40008-019-0160-4.

Shanthy, T. R. (2011). Strategies for effective dissemination of appropriate technologies to sugarcane growers in India. Sugar Tech, 13(4), 354-359.Available at: https://doi.org/10.1007/s12355-011-0111-3.

Siddick, S. A. (2019). Appropriate technologies for improving yield and income of small holders growing rice paddy in rainfed low lands of agro-biodiversity hotspots in India. Agricultural Sciences, 10(11), 1497-1505.Available at: https://doi.org/10.4236/as.2019.1011110.

Singh, A. K. (2017). An empirical analysis to assess the GDP projection of Gujarat state of India. JNNCE Journal of Engineering and Management, 1(2), 51-58.

Singh, A. K., \& Jyoti, B. (2021a). Projected productivity of cash crops in different climate change scenarios in India: Use of marginal impact analysis technique. Finance \& Economics Reviere, 3(1), 63-87.

Singh, A. K., \& Jyoti, B. (2021b). Projected food-grain production and yield in India: An evidence from state-wise panel data investigation during 1977-2014. The Journal of Agricultural Sciences - Sri Lanka, 16(1), 108-125.Available at: https://doi.org/10.4038/jas.v16i1.9188.

Singh, A. K., \& Sharma, P. (2018). Measuring the productivity of food-grain crops in different climate change scenarios in India: An evidence from time series investigation. Climate Change, 4(16), 661-673.

Singh, A. K., Sharma, P., \& Singh, D. K. (2016). Measuring the influence of weather variables on productivity of food-grain crops in India: An application of Just \& Pope's production Technique. AMBER-ABBS Management Business and Entrepreneurship Review, 7(2), 29-46.Available at: https://doi.org/10.23874/amber/2016/v7/i2/121780.

Singh, A. K., Narayanan, K., \& Sharma, P. (2017). Effect of climatic factors on cash crop farming in India: An application of Cobb-Douglas production function model. International Journal of Agricultural Resources, Governance and Ecology, 13(2), 175-210.Available at: https://doi.org/10.1504/ijarge.2017.10007474.

Sinha, J. K. (2019). Influence of technologies on the growth rate of GDP from agriculture: A case study of sustaining economic growth of the agriculture sector in Bihar. Statistical Journal of the IAOS, 35(2), 277-287.Available at: https://doi.org/10.3233/sji-180436.

Suresh, R. B. (2010). Organic farming: Status, issues and prospects-a review. Agricultural Economics Research Review, 23(2), 343358.

Suryavanshi, P., \& Singh, K. V. (2014). Biotechnology-An effective tool for food security in India. Kurukshetra A Journal on Rural Development, 62(8), 42-46.

Yadav, S., Babu, S., Singh, Y., Yadav, G., Singh, K., Singh, R., \& Singh, H. (2013). Effect of organic nitrogen sources and biofertilizers on production potential and energy budgeting of rice (Oryza sativa)-based cropping systems. Indian Journal of Agronomy, 58(4), 459-464.

Zilberman, D., Khanna, M., \& Lipper, L. (1997). Economics of new technologies for sustainable agriculture. Australian Journal of Agricultural and Resource Economics, 41(1), 63-80.Available at: https://doi.org/10.1111/1467-8489.00004.

Views and opinions expressed in this article are the views and opinions of the author(s), Asian Development Policy Review shall not be responsible or answerable for any loss, damage or liability etc. caused in relation to/arising out of the use of the content. 